\title{
School Management of Multiculturalism in Early Childhood Education to Develop the Student's Social Skills
}

\author{
Lanny Wijayaningsih \\ Early Childhood Education Program, Universitas Kristen Satya Wacana Salatiga, Jawa Tengah, Indonesia \\ Corresponding e-mail: Lanny.wijayaningsih@staff.uksw.edu/lanny.wijayaningsih@yahoo.com
}

\begin{abstract}
Many countries in the world have become more heterogeneous as a result of various social, economic and politic developments. This is also reflected in Indonesia schools where Learners come from different racial and ethnic backgrounds, speaking different languages now increasingly have to be accommodated. In recent times, early childhood education is becoming more diverse. These differences of multiculturalism are required with a global focus on human rights and equal educational opportunities. The best time to start this process of education is right from early childhood. That is the reality that early childhood education have to face and manage it well. School management of multiculturalism in early childhood education approach according equal recognition to all cultural groups and providing all leaners with a meaningful and relevant educational experiences the purpose of this study. ssThe purpose of this study is to develop the student's social skills through and understanding of inter-ethnic interaction among students of various ethnic groups in early childhood education. By those, Teaching with a multicultural perspective encourages appreciation and understanding of other cultures as well as one's own. The methodology of this research, through observation of 20 student's kindergarten in age 5-6 years using the scale rating. There are 7 aspects of social skills to measure the development of student's social skills. The result indicated that more than half of 20 students are having good aspect in social skills but some of them need improvement to adjust with the situation. The other goals of multicultural programs are to encourage cooperative social skills, as they learn to accept differences and similarities among people, they can work and get along with other better. The early childhood program that is culturally sensitive will build the self-confidence of its children by integrating the cultures of all the children into learning experiences.
\end{abstract}

Keywords: school management, multiculturalism in early childhood, student's social skill

\section{INTRODUCTION}

Now days multiculturalism education in Indonesia is becoming more needed because of Indonesia has many ethnic groups and cultural groups with the motto "Bhineka Tunggal Ika", this is also reflected in Indonesian school must begin a focused and concerted effort to provide for today's children the skill, attitudes and knowledge so they will be successful in the pluralistic situation. (Abdullah, A.C. 2009). Most schools are looking for ways of educating a diverse learners in classroom as socially, linguistically and economically diverse. The best time to start this process of education is right from early childhood. That is the reality that early childhood education have to face and manage it well.
School management of multiculturalism plays an important role in implementary multicultural education in the classroom (Smith .B 2010). The aspects that should be manage in multiculturalism education are: curriculum orientation, pedagogy and resources, access to an enrollment, services, instructional resources, recruitment and professional development of education staff. It is important to ensure teachers develop more critical understanding of multicultural education through teachers overcome challenges in implementing multicultural education include producing and developing more instructional materials and learning aids which are suitable for young children and appropriate for the local context. (Berthelsen, 2011). The other aspect is parental involvement in multicultural school would 
be contributed a good atmosphere in teaching learning. The benefits of parent - teacher cooperation are strongly supported to lead in improving academic student achievement, selfesteem, school attendance and also social behavior, a reduction in school dropout rates. More positive parent-child communication, improved school programmers and school climate. (Henderon Mapp, 2002). Creating multicultural classroom is growing priority for all teachers and administrators, this includes restricting the curriculum and classroom evaluation, but more importantly that it includes embracing differences and opening up the classroom for communication.

As the early childhood population becomes more diverse, there is a need to incorporate programs and practices that are reflective of multicultural education principles. These young children will benefit greatly from early childhood programs in early childhood education approach according equal recognition to all cultural groups and providing all learners with a meaningful and relevant educational experiences. (Robinson, K, 2006)

The ideal of multiculturalism involves achieving a positive sense of self and worth in a person's own culture along with tolerance, contact and sharing with other through the school programs and activities that always accommodate multiculturalism in the inclusive classroom. By those, teaching with multicultural perspective in early childhood encourages appreciation and understanding of other cultures as well as one's own (Abdullah, 2009). Teaching with the perspective promotes the child's sense of the uniqueness of their own cultures as a positive characteristic and enables the child to accept the uniqueness of cultures of others too. Children learn that people can be different and unique so such realizations help young children learn to accepts differences and as the end in eliminating prejudice and racism. This realizations assist children with accepting and respecting people from all cultures are to encourage cooperative social skills, they can learn to accept differences and similarities among people and they can work and get along with other better. (Sheets .R, 2009). The other purposes are culturally sensitive will build the self-confidence of children by integrating the cultures of all the children into learning experiences that makes children develop their social skills. The purpose of this study is to develop the student's social skills through and understanding of inter-ethnic interaction among students of various ethnic groups in early childhood education.

\section{LITERATURE REVIEW}

The needs of the $21^{\text {st }}$ century demand a citizen that is culturally sensitive and internationally focused, with an orientation toward the future rather than the past (Zirkel, S. 2008). The Indonesian demographic landscape that have the society of multicultural backgrounds with multiple ethnic groups, social and economic groups need to accommodate this diversification through the multicultural education.

\subsection{What is Multiculturalism?}

The concept of multiculturalism embodies a new orientation toward the future and refers to the sharing of many cultures (Bennet. C. 2003). Multiculturalism is a system of belief and behavior that recognizes and respects the presence of all diverse groups in an organization or society, acknowledges and values their socio-cultural differences, and encourages to enables their contribution within inclusive cultural context which empower all the organization or society. (Bank, 2004). The essence of multiculturalism is the undergirding concept of multicultural education of the ability to celebrate with other in a manner that transcends all barriers and brings about a unity in diversity (Sleeter, C.E. 2007).

Multiculturalism enables us to look upon the other, especially the other that society has taught us to regard others in an age of cultural pluralism. Multiculturalism is also needed to manage diversity effectively by opening educators, leaders and administrators in an ever culturally pluralistic environment and the process of multiculturalism is the best maintained through multicultural education. (Verma G.K, 2003).

\subsection{Why Multicultural Education?}

Multicultural education refers to the learning of appropriate knowledge, attitudes and skills related to the respect and appreciation of different cultures and others differences which include race, ethnicity, religion, etc. (Gollnick, 2000). Gollnick recommend five goals for multicultural education. These goals also emphasize issues beyond the boundaries of 
ethnic or racial issues. They include: the promotion of strength and value of cultural diversity, an emphasis on human rights and respect for those who are different from one self, the acceptance of alternative life choices for people, the promotion of social justice and equality for all people, and an emphasis an equal distribution of power and income among groups.

The research has shown that "the prime time" for emotional and social development in children is birth to 12 years of age. (Bennett, 2003). Differing aspects of emotional and social development, which incorporate higher capacities, such as awareness of others, empathy and trust are important to teach in early childhood. The part of the brain that regulates emotion is shaped early on by experience ad forms the brain's emotional wiring. Early nurturing is important to learning empathy, happiness, hopefulness and resiliency, social development which involves both self, awareness and a child's ability to interact with others also occurs in this stages and it is good to nurture and guide a child will assist in laying healthy foundations for social and emotional development to get the emotional intelligence which is critical to life success. There are suggestions that multicultural education should be reserved for older children who are less egocentric or ethnocentric. Lynch -Hanson (2000) said that cultural understanding in one's first culture occurs early and is typically established by age 5 . Children leave now cultural patterns more early than adults, and young children are capable of learning that we are all alike and all different in certain ways. In fact, research has also demonstrated that children are not totally free of bias and prejudice. It is shown that children as young as three notice differences such as skin, eye and hair colour. As part of their socialization, children develop their self-identity by comparing their own selves with others. They learn that they belong to certain groups and not to others due to certain visible similarities and differences. Through observing how others around them react and respond to these differences. They see what is valued and what is not. They start to develop positive or negative feelings about the difference observed, so it is the best that young children having been socialized with diverse to develop their owns selecting about good or bad for their life.

School management of multiculturalism plays an important role in implementary multicultural education in the classroom, the aspects that should be manages are: curricula, instructional practices, and school community relations acceptance and respect for human diversity as a means of providing all children and equality education in preparing for living in a culturally pluralistic society. (Tasman, 2011). It is all should be implemented in school's program and activities that includes are in the curriculum of multiculturalism education. All aspects of education needed to be transformed in order to create a multicultural school environment. (Banks, JA, 2004). These aspects include teaching methods, instructional materials, teacher attitudes, and the performance of students. (Banks, 2001) also described five areas of multicultural education in which teacher and researches are involved: 1) content integration: concepts, values, material's from a variety of cultures are includes in teaching, 2) knowledge construction $=$ this belief asserts that all knowledge is created in the minds of human beings and can be changed also the challenges teachers to alter their own perceptions of the world before they can teach multicultural, 3) equity pedagogy= teacher must modify their methods of instruction by following for students cultural differences before they can encourage academic achievement, 4) prejudice reduction teacher must work to shift student's prejudices regarding race and ethnicity. Prejudice reduction may also encompass teaching the tolerance of various religions, sexual preferences and disabilities, 5) empowering school culture: schools must identify those aspects of education that hinder learning and then empower families and students from all backgrounds, so that the full development of students is achieved.

\subsection{Types of Multicultural Education Programs}

The demand of curricula that were more supportive and consistent with the cultural and racial diversity should be implemented in the school's program, such as: the multicultural festival approach, in which students are invited to celebrate ethnic diversity by 
being exposed to foods, holidays, and festivals of other cultures. (Najemah M.Y. 2005). Multicultural education can also be divided into three different categories: 1) content focused: these all the most common types of multicultural educational programs, their overall objective is to include subject matter in the curriculum about various cultural groups in order to cultivate student's knowledge about these groups. Content may include holiday celebrations, recognizing heroes from different racial and ethnic groups and focusing single group's studies, for example: black ethnic or woman's studies programs. 2) student-focused: many programs go beyond changes in the curriculum and specifically address the academic needs of defined groups of students usually minorities. 3) Socially focused: these programs seek to reduce bias and increase cultural and racial tolerance. Included here might be desegregation programs that designed to increase contact among different races and cultures. (Dixon G.T. 2000).

\subsection{Multiculturalism Education Develop Student's Social Skills}

Definition of social skills or prosocial behaviors is socially acceptable learned behaviors that enable an individual to interact effectively with others and to avoid or escape negative social interactions with others (Gresham \& Elliot, 2000). The major categories of social skills are:

1) Communication: takes turn in conversation, make eye contact when talking.

2) Cooperation: follow the direction and classroom rules.

3) Assertion: ask for help from adult, questions rules that may be unfair.

4) Responsibility: respects the property of others, takes responsibility from own action.

5) Empathy: forgives others, feels bad when others are sad.

6) Engagement: makes friends easily, invites others to join in activities.

7) Self-control: makes a compromise during a discussion, stay calm when teased.
(Caprara, Barbaranell, 2000) found that prosocial skills: Cooperating, helping, sharing and consoling in $3^{\text {rd }}$ grade academic achievement.

(Malecki \& Elliot, 2002) reported similar findings for social skills and problems behaviors for an elementary sample, with social skills significantly predicting end of year achievement test performance on a high stakes test.

\section{DISCUSSION AND CONCLUSION}

Multiculturalism education in early childhood should be constructed in the classroom setting that provide every child opportunity to: construct a knowledgeable, confident self-identity, develop comfortable, emphatic and just interactions with diversity and develop critical thinking skills and the skills for standing up for self and others in the face of injustice. In order to achieve above, early childhood setting need to prepare an environment which present diversity positively through resources and materials that do not perpetuate stereotypes but it should be implemented in student's social skills.

This research has also shown that students are placed in multiculturalism education to get along in cooperative learning situations can proved their social skills are develop more positively: from 20 students are observed in age 5-6 years. The aspect of communication got $75 \%$ and the cooperation got $80 \%$, the assertion got $60 \%$, the responsibility got $65 \%$, the empathy get $70 \%$. The engagement got $85 \%$ and self-control got $80 \%$. It is indicated that more than $50 \%$ of 20 students are having good aspect in social skills. But some of them need improvement to adjust with the situation.

Hartop W. (1992) said "the single best childhood predictor of adult adaption is not school grades, and not classroom behavior, but rather the adequacy with which the child gets along with other children. Children who are aggressive and destructive, who are unable to sustain close relationship with other children and who cannot establish a place for they in the peer culture are seriously at risk.

Observations done in the early childhood school, found that teachers are not competent enough regarding to multiculturalism. Teacher should be competent in the context of actual pluralism will mean being able to participate effectively in a multicultural world. It will mean being "bicultural" as well as bilinguals. An important step in teaching children to be comfortable with their cultural background and essentially 
themselves is to encourages and value them input in a small group of other students. This has to do with the organization of the classroom and the development of lesson plans, when grouping students, teachers should put students from differing backgrounds and ethnic together. An accomplished teacher should be able to create projects for a group of students from different backgrounds and ethnic groups that will require students to work together. Therefore allowing each student to be an important part of the group and learn information through the interaction of the group. Lesson plans that can do this and interest students will become invaluable for teachers to possess as the need for teachers to become culturally fluent continues to grow, this is rarely done in the schools observed. The purpose of multicultural curriculum is to attach positive feelings to multicultural experiences so that each child will feel included and valued, and also will feel friendly and respectful toward people from other ethnic and cultural groups, so children become accustomed to the idea that there are many lifestyles, languages, cultures, and point of view because over world is multicultural and colorful world so let the teachers to make sure that we paint our classroom with many colours in every single day.

\section{REFERENCES}

Abdullah, A.C (2009). Multicultural Education Early Childhood: Issues and Challenges, Journal of International Cooperation in education.

Banks, JA (2004). Multicultural education: Historical Development dimensions and practices. In, JA Banks: Handbook of research on multicultural education, New York, Macmillan Publishing Company.

Bennet, C. (2003). Comprehensive Multicultural education: The Theory and Practice, Boston, M.A: Allyn Bacon

Berthelsen, D (2011). Multicultural Education: The Understandings of preschool teachers in Singapore. Australian Journal of early childhood education.

Dixon G.T (2000). Teaching Preschool, in multilingual classroom childhood education, English Journal.

Gollnick, D (2000). Multicultural education in pluralistic society. New York, Macmillan.

Gresham \& Elliot (2000). Social Skills Development in Early Childhood. Arizona State University.

Hartup W. (2000). Having Friends, making friends and keeping friends, relationships as educational contexts. Eric Digest Champaign
Henderson A.T \& Mapp K. (2002). A New Wave of Evidence the Impact of School, family, community connections on student achievement, Australia South West educational laboratory.

Jones \& Charlotte M. (2001). Practice Applications of Multicultural Communication Theory in the classroom setting, Fresro, CA.

Najemah, M.Y (2005). Multicultural education Practice among teachers on international secondary schools: a case study in Kedah. Educations and Education Journal.

Robinson K (2006). Diversity and Differences in early childhood education. Berks-Open University Press.

Sheets, R. (2009). What is diversity Pedagogy? Multicultural education. New York: Teacher College Press.

Sleeter, C.E (2007). Making choices for multicultural education. New York, Wiley.

Smith. B (2010). Managing Multicultural Schools: New York, Harper Collins.

Tasman I (2001). Developing Effective Multicultural Practices: A Case Study of exploring a teacher's understanding and practices. The Journal of International Social Research.

Verma G.K (2003). Ethnic Diversity and Multicultural Education Cross. Catting issues and concepts. Proceedings of the international conference on globalization and multicultural perspectives in education. Penang-Malaysia

Zirkel, S. (2008). The Influence of Multicultural education practices student's outcomes and intergroup relations. Teacher college record 